\title{
Genetic diversity in natural populations of mangaba in Sergipe, the largest producer State in Brazil
}

\author{
A.N.R. Soares ${ }^{1}$, M.F. Vitória ${ }^{1}$, A.L.S. Nascimento ${ }^{2}$, A.S. Ledo ${ }^{2}$, \\ A.R.C. Rabbani ${ }^{3}$ and A.V.C. Silva ${ }^{2}$ \\ ${ }^{1}$ Graduate Program in Agriculture and Biodiversity, \\ Federal University of Sergipe, Aracaju, SE, Brasil \\ ${ }^{2}$ Embrapa Tabuleiros Costeiros, Aracaju, SE, Brasil \\ ${ }^{3}$ Instituto Federal da Bahia, Porto Seguro, BA, Brasil \\ Corresponding author: A.V.C. Silva \\ E-mail: ana.veruska@embrapa.br
}

Genet. Mol. Res. 15 (3): gmr.15038624

Received March 21, 2016

Accepted April 25, 2016

Published August 18, 2016

DOI http://dx.doi.org/10.4238/gmr.15038624

Copyright (C) 2016 The Authors. This is an open-access article distributed under the terms of the Creative Commons Attribution ShareAlike (CC BY-SA) 4.0 License.

\begin{abstract}
Mangaba (Hancornia speciosa Gomes) is found in areas of coastal tablelands in the Brazilian Northeast and Cerrado regions. This species has been subjected to habitat fragmentation that is mainly due to human activity, and requires conservation strategies. The aim of this study was to analyze the structure and inter- and intrapopulation genetic diversity of natural populations of $H$. speciosa Gomes using inter-simple sequence repeat (ISSR) molecular markers. A total of 155 individuals were sampled in 10 natural populations (ITA, PAC, IND, EST, BC, PIR, JAP, BG, NEO, and SANT) in the State of Sergipe, Brazil. Fifteen primers were used to generate 162 fragments with $100 \%$ polymorphism. Genetic analysis showed that the variability between populations $(77 \%)$ was higher than within populations $(23 \%)$. It was
\end{abstract}


possible to identify five different groups by the unweighted pair group method with arithmetic mean and principal coordinate analysis, and only one individual (E10) remained isolated. Using ISSR markers it was possible to obtain a molecular profile of the populations evaluated, showing that these markers were effective and exhibited sufficient polymorphism to estimate the genetic variability of natural populations of $H$. speciosa Gomes.

Key words: Genetic variability; Hancornia speciosa Gomes; ISSR marker; Species preservation

\section{INTRODUCTION}

Mangaba (Hancornia speciosa Gomes, Apocynaceae) is a fruit tree species that is native to Brazil, and has social, economic, and cultural importance in the areas where it occurs. Sergipe State is the largest producer of this fruit, which is found in natural populations and is exploited almost entirely in an extractive way.

The fruit of this plant is popular due to its organoleptic characteristics and high nutritional value, being rich in the vitamins $\mathrm{A}, \mathrm{B} 1, \mathrm{~B} 2$, and $\mathrm{C}$, as well as phosphorus, calcium, and proteins (Barros et al., 2006). Its pulp is the main product, and it is consumed in natura or as raw material for the manufacture of products such as jam, ice cream, juice, jelly, sauce, wine, and vinegar (Costa et al., 2011). Consequently, the species has aroused the interest of the industry and trade sectors (Ganga et al., 2010).

In the Brazilian Northeast, the extraction of genetic resources undergoes accelerated genetic erosion due to large real estate pressure on the coastal lowlands (Santos et al., 2010). Therefore, studies on the genetic diversity and structure of the remaining populations of mangaba are extremely important, in order to find alternatives for the species' preservation (Amorim et al., 2015). In addition, the domestication and incorporation of this species into production systems is directly related to knowledge of the range and distribution of genetic variability in natural populations (Costa et al., 2011).

One way of evaluating genetic diversity is by using molecular markers, which are defined as DNA-identifiable sequences specific to the genome, and provide information on genetic variability by eliminating environmental effects. Few studies have used molecular markers to describe this variability in natural populations of mangaba (Silva et al., 2012b). Among the different molecular markers, inter-simple sequence repeats (ISSRs) are widely used to assess genetic diversity in plants (Liu et al., 2011). They are dominant markers, are based on the amplification of DNA regions by polymerase chain reaction (PCR), and combine many of the advantages of amplified fragment length polymorphism markers and microsatellites. They are highly polymorphic, reproducible, and do not require prior knowledge of the genome. Moreover, they are relatively cheap (Souza et al., 2004). ISSR markers are important tools for the analysis of genetic diversity, as well as for the characterization of accessions and cultivars of several species.

Morales et al. (2011) evaluated the genetic divergence of 11 strawberry cultivars, and found that this type of molecular marker is effective in the formation of groups in the study of genetic diversity. Dias et al. (2015) used nine ISSR markers in early and erect cowpea genotypes, and concluded that these markers were effective in estimating genetic variability.

Genetics and Molecular Research 15 (3): gmr.15038624 
ISSRs used in a study on the genetic diversity of Elaeis guineensis were effective in detecting genetic variability in this species (Chagas et al., 2015).

Using microsatellite markers in mangaba, Amorim et al. (2015) estimated the divergence and genetic structure of natural populations in the Brazilian Northeast, and found low genetic diversity in populations in Sergipe State. Therefore, the objective of this study was to estimate genetic variability in 10 natural populations of mangaba in the State of Sergipe using ISSR markers.

\section{MATERIAL AND METHODS}

\section{Sampling, collection, and DNA extraction}

Young leaves were collected from 155 individuals in 10 natural populations of mangaba in the State of Sergipe (Figure 1 and Table 1).

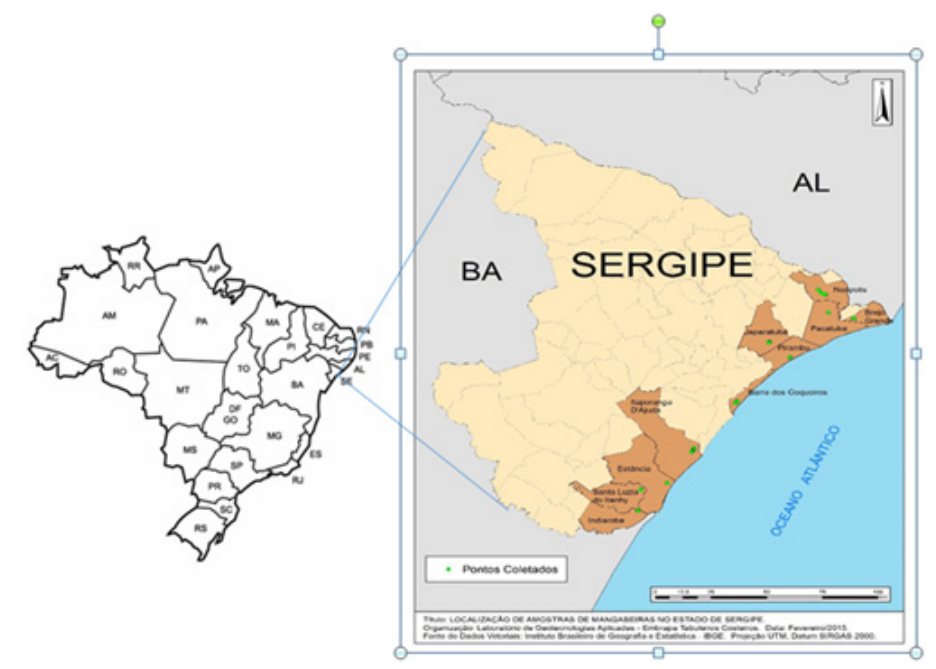

Figure 1. Location of natural populations of Hancornia speciosa Gomes in the State of Sergipe, Brazil, where samples were collected for the analysis of structure and genetic diversity.

Table 1. Identification, geographical location, and number of Hancornia speciosa Gomes samples collected in Sergipe, Brazil.

\begin{tabular}{|c|c|c|c|}
\hline Population & Geographical coordinates & No. of individuals & Code \\
\hline Itaporanga & $11^{\circ} 8^{\prime} 30^{\prime \prime S}$ and $37^{\circ} 11^{\prime} 18^{\prime \prime} \mathrm{W}$ & 19 & Ita \\
\hline Pacatuba & $10^{\circ} 29^{\prime} 35^{\prime \prime} \mathrm{S}$ and $36^{\circ} 32^{\prime} 42^{\prime \prime} \mathrm{W}$ & 20 & Pac \\
\hline Indiaroba & $11^{\circ} 26^{\prime} 25^{\prime \prime} \mathrm{S}$ and $37^{\circ} 24^{\prime} 30^{\prime \prime} \mathrm{W}$ & 20 & Ind \\
\hline Estância & $11^{\circ} 18^{\prime} 20^{\prime \prime S}$ and $37^{\circ} 17^{\prime} 42^{\prime \prime} \mathrm{W}$ & 20 & Est \\
\hline Barra dos Coqueiros & $10^{\circ} 54^{\prime} 21^{\prime \prime} \mathrm{S}$ and $37^{\circ} 1^{\prime} 18^{\prime \prime} \mathrm{W}$ & 20 & $\mathrm{Bc}$ \\
\hline Pirambu & $10^{\circ} 40^{\prime} 15^{\prime \prime S}$ and $36^{\circ} 47^{\prime} 27^{\prime \prime} \mathrm{W}$ & 19 & Pir \\
\hline Japaratuba & $10^{\circ} 36^{\prime} 52^{\prime \prime} \mathrm{S}$ and $36^{\circ} 52^{\prime} 10^{\prime \prime} \mathrm{W}$ & 5 & Jap \\
\hline Brejo Grande & $10^{\circ} 27^{\prime} 45^{\prime \prime} \mathrm{S}$ and $36^{\circ} 38^{\prime} 14^{\prime \prime} \mathrm{W}$ & 15 & $\mathrm{Bg}$ \\
\hline Neópolis & $10^{\circ} 22^{\prime} 19^{\prime \prime} \mathrm{S}$ and $36^{\circ} 39^{\prime} 22^{\prime \prime} \mathrm{W}$ & 15 & Neo \\
\hline Santa Luzia & $11^{\circ} 19^{\prime} 25^{\prime \prime} \mathrm{S}$ and $37^{\circ} 24^{\prime} 12^{\prime \prime} \mathrm{W}$ & 2 & Sant \\
\hline Total & & 155 & \\
\hline
\end{tabular}

Genetics and Molecular Research 15 (3): gmr.15038624 
Leaves of each individual were collected separately, and were ice-packed in order to prevent oxidation. Subsequently, they were transported to the Molecular Biology Laboratory of Embrapa Coastal Tablelands, Aracaju, SE, Brazil. Samples remained in the freezer at $-80^{\circ} \mathrm{C}$ until genomic DNA extraction. DNA extraction was conducted using the method described by Doyle and Doyle (1990) and modified by Alzate-Marin et al. (2009). DNA quantification was performed using a NanoDrop ${ }^{\mathrm{TM}} 2000 \mathrm{c}$ spectrophotometer (Thermo Scientific, USA). Samples were stored at $-20^{\circ} \mathrm{C}$ for subsequent use in PCRs.

\section{PCR amplification}

Fifteen ISSR primers obtained from the University of British Columbia, Vancouver, Canada, were used to estimate the genetic diversity of the 155 mangaba individuals (Table 2).

For the PCR, the total volume of the reaction was $20 \mu \mathrm{L}$, which contained $2 \mu \mathrm{L}$ genomic DNA solution, $2 \mu \mathrm{L}$ of each primer with a compound mix of $2 \mu \mathrm{L} 10 \mathrm{X}$ PCR buffer, $0.4 \mu \mathrm{L}$ dNTP $(10 \mathrm{mM}), 0.6 \mu \mathrm{L} \mathrm{MgCl}_{2}(50 \mathrm{mM}), 0.2 \mu \mathrm{L} \mathrm{Taq}$ DNA polymerase $(5$ $\mathrm{U} / \mu \mathrm{L}$; Invitrogen), and $12.8 \mu \mathrm{L}$ ultrapure water. For reaction amplification, the thermal cycler (ProFlex ${ }^{\mathrm{TM}}$, Applied Biosystems, USA) was programmed so that the samples were denatured at $95^{\circ} \mathrm{C}$ for $5 \mathrm{~min}$ followed by 45 amplification cycles. At each cycle, the samples underwent denaturation at $94^{\circ} \mathrm{C}$ for $1 \mathrm{~min}$, annealing at different temperatures for $45 \mathrm{~s}$, and a final extension at $72^{\circ} \mathrm{C}$ for $2 \mathrm{~min}$.

The result of the amplification was subjected to horizontal electrophoresis on $2 \%$ agarose gels. The gels were then placed in contact in a solution containing ethidium bromide $(0.5 \mu \mathrm{L} / \mathrm{mL}$ water) for $1 \mathrm{~h}$, and visualized under ultraviolet light. For the measurement of fragment patterns, we used a 1-kb molecular weight marker (Promega, Madison, SD, USA). Visualization of the results was conducted using a Gel Doc L-Pix photodocumentation device (Loccus Biotecnologia, Cotia, SP, Brazil).

\section{Data analysis}

The ISSR fragments were converted into a binary matrix based on the presence (1) or absence (0) of fragments. Data were imported into the TreeView software (Page, 1996), and the distribution of genetic variability in each population was estimated based on the Shannon index $(I)$, the expected heterozygosity $\left(H_{\mathrm{E}}\right)$, and analysis of molecular variance (AMOVA). The same software was used to estimate genetic distances according to the Jaccard coefficient, and the respective dendrograms were constructed based on the unweighted pair group method with arithmetic mean (UPGMA).

The consistency of the clustering was analyzed by bootstrap resampling $(10,000$ iterations). Principal coordinates analysis (PCoA) was conducted using the GenALEx 6.3 software (Peakall and Smouse, 2006), which was also used to estimate $I$ (Brown and Weir, 1983) and $H_{\mathrm{E}}$ (Lynch and Milligan, 1994).

\section{RESULTS AND DISCUSSION}

Of the 15 primers tested, 162 fragments were amplified with $100 \%$ polymorphism, showing high genetic variability between the populations. This may have been due to the allogamy of this species that results in self-incompatibility, and thus makes plants derived

Genetics and Molecular Research 15 (3): gmr.15038624 
from seeds highly divergent from each other in relation to the parent plant (Darrault and Schlindwein, 2006). The number of fragments ranged from five (UBC 810) to 22 (UBC 817) (Table 2).

Table 2. Inter-simple sequence repeat (ISSR) primers used in natural populations of Hancornia speciosa Gomes from the State of Sergipe, Brazil, with their respective sequences, annealing temperatures, total fragments, polymorphic fragments, and polymorphism percentages (PP).

\begin{tabular}{|c|c|c|c|c|c|}
\hline ISSR primer & Sequence (5'-3') & Annealing temperature $\left({ }^{\circ} \mathrm{C}\right)$ & Total fragments & Polymorphic fragments & $\mathrm{PP}(\%)$ \\
\hline UBC 807 & AGA GAG AGA GAG AGA GT & 50.4 & 7 & 7 & 100 \\
\hline UBC 809 & AGA GAG AGA GAG AGA GG & 57.2 & 12 & 12 & 100 \\
\hline UBC 810 & GAG AGA GAG AGA GAG AT & 50.4 & 5 & 5 & 100 \\
\hline UBC 811 & GAG AGA GAG AGA GAG AT & 53.0 & 7 & 7 & 100 \\
\hline UBC 812 & GAG AGA GAG AGA GAG AA & 54.8 & 13 & 13 & 100 \\
\hline UBC 815 & CTC ТTC ТCT СТC ТCТ CTG & 52.8 & 9 & 9 & 100 \\
\hline UBC 816 & CAC ACA CAC ACA CAC AT & 54.8 & 6 & 6 & 100 \\
\hline UBC 817 & CAC ACA CAC ACA CAC AA & 50.4 & 22 & 22 & 100 \\
\hline UBC 818 & CAC ACA CAC ACA CAC AG & 57.2 & 14 & 14 & 100 \\
\hline UBC 823 & TCT СТC ТCТ СТС ТСТ СC & 57.2 & 6 & 6 & 100 \\
\hline UBC 825 & ACA CAC ACA CAC ACA CT & 54.8 & 15 & 15 & 100 \\
\hline UBC 828 & TGT GTG TGT GTG TGT GA & 54.8 & 8 & 8 & 100 \\
\hline UBC 834 & AGA GAG AGA GAG AGY T & 52.8 & 7 & 7 & 100 \\
\hline UBC 848 & CAC ACA CAC ACA CAC ARG & 53.0 & 18 & 18 & 100 \\
\hline UBC 855 & ACA CAC ACA CAC ACA CYT & 53.0 & 13 & 13 & 100 \\
\hline
\end{tabular}

Several studies on natural populations use the percentage of polymorphic loci as an important measure of genetic diversity. However, although it is widely used, wide variations in this value are found, e.g., Black-Samuelsson et al. (1997) reported very low polymorphism levels (around 7\%) in Vicia pisiformis, whereas Brandão et al. (2011) found between 83 and $89 \%$ polymorphic loci in Myrcia splendensm using ISSR markers. There is significant variation in these percentages, probably due to the ecological characteristics of each species, the different individuals and populations sampled, and the type of marker used.

Coefficient of variation stabilization occurred in 120 fragments, with values lower than $10 \%$, indicating that the results could be used to analyze the genetic diversity of these populations (Figure 2). Markers based on ISSR have been successfully used in estimating genetic variability in wild and cultivated species, both between and within populations (Uysal et al., 2010).

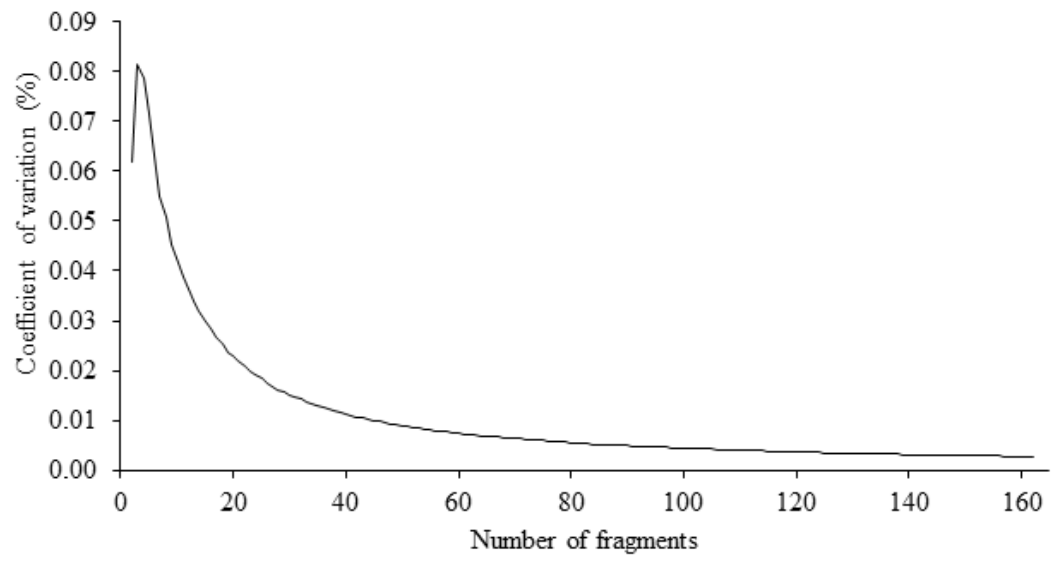

Figure 2. Coefficient of variation for the number of polymorphic fragments using ISSR markers among 10 natural populations of Hancornia speciosa Gomes of the State of Sergipe, Brazil. 
The $100 \%$ polymorphism value that we obtained was higher than that reported in the literature for the use of ISSR molecular markers in Spondias sp, in which the polymorphism percentage was reported to be $80 \%$ (Santana et al., 2011). Amorim et al. (2013) obtained 51 fragments, $86 \%$ being polymorphic, when conducting the molecular characterization of native mangaba using 14 ISSR primers. Several studies that have used dominant markers, such as ISSRs, consider the percentage of polymorphic loci as a genetic diversity measure (Lorenzoni et al., 2014).

The mean genetic diversity value was 0.83 and the mean $I$ value was 1.26 . Estimated values for $I$ within each population ranged from 0.05 (Pacatuba population) to 0.16 (Barra dos Coqueiros and Neópolis populations) (Table 3). The closer to zero is the value of $I$, the lower is the diversity (Souza-Sobreira et al., 2015). Under natural conditions, it is expected that these values are different from zero. Genotypes may incorporate new alleles by crossing, losses in small populations, or in populations fragmented by genetic drift (Barreira et al., 2006). These results agree with those reported by Costa et al. (2011), who obtained low values of $I$ and $H_{\mathrm{E}}$ in H. speciosa Gomes germplasm.

Table 3. Number of individuals, Shannon index $(I)$, and expected heterozygosity $\left(H_{\mathrm{E}}\right)$ in natural populations of Hancornia speciosa Gomes obtained by inter-simple sequence repeat markers.

\begin{tabular}{l|c|c|c}
\hline Population & No. of individuals & $I$ & $H_{\mathrm{E}}$ \\
\hline Itaporanga & 19 & 0.13 & 0.09 \\
\hline Pacatuba & 20 & 0.09 & 0.06 \\
\hline Indiaroba & 20 & 0.12 & 0.08 \\
\hline Estância & 20 & 0.16 & 0.11 \\
\hline Barra dos Coqueiros & 20 & 0.16 & 0.1 \\
\hline Pirambu & 19 & 0.14 & 0.09 \\
\hline Japaratuba & 5 & 0.10 & 0.07 \\
\hline Brejo Grande & 15 & 0.15 & 0.10 \\
\hline Neópolis & 15 & 0.16 & 0.10 \\
\hline Santa Luzia & 2 & 0.05 & 0.03 \\
\hline Total & 155 & 1.26 & 0.83 \\
\hline
\end{tabular}

The genetic diversity indices used in this study $\left(I\right.$ and $H_{\mathrm{E}}$ ) revealed low levels of genetic diversity within the populations evaluated. By observing the standard deviations of the $H_{\mathrm{E}}$ estimates, it was noted that the diversity levels were similar in all of the populations. The existence of high genetic diversity among populations can be confirmed when comparing values of $I$ with those of other tree species. Similar results were found by Rivas et al. (2013) and Giustina et al. (2014) in natural populations of two allogamous species of the Amazon forest (Theobroma subincanum Mart. and Theobroma speciosum Willd. Ex Spreng.), who reported that there was great interpopulation genetic variability. However, Amorim et al. (2015), using microsatellite markers in mangaba, observed greater variation within populations $(83.18 \%)$ than between them (10.82\%).

Based on the ISSR markers, the similarity matrix obtained from the 155 individuals resulted in 18,769 values for the dissimilarity index, 21 of which stood out as having the highest and lowest dissimilarities (Table 4). The pairs formed between the individuals 15 x $14(\mathrm{IN} \mathrm{x} \mathrm{IN)} \mathrm{and} 2$ x 10 (S x E) had the highest (0.996) and lowest (0.555) similarities, respectively, and most pairs with the highest similarities belonged to the same populations and those with the lowest belonged to different populations. The reproductive system can influence the degree of genetic variability by both homogenizing and increasing divergence between individuals and populations (Zanella et al., 2012).

Genetics and Molecular Research 15 (3): gmr.15038624 
Table 4. Pairs of genotypes that had extreme values of high and low similarity (s) based on the Jaccard coefficient from 15 inter-simple sequence repeat markers in 155 individuals of Hancornia speciosa Gomes.

\begin{tabular}{|c|c|c|c|c|c|c|}
\hline Order & & hest similarity & & & west similarit & \\
\hline & Individuals & Populations & $\mathrm{s}$ & Individuals & Populations & $\mathrm{s}$ \\
\hline 1 & $7 \times 6$ & Ix I & 0.958 & $5 \times 1$ & BG x I & 0.075 \\
\hline 2 & $11 \times 12$ & I x I & 0.885 & $13 \times 1$ & BG x I & 0.082 \\
\hline 3 & $12 \times 9$ & Ix I & 0.935 & $10 \times 7$ & BG x I & 0.067 \\
\hline 4 & $3 \times 2$ & $\mathrm{P} \times \mathrm{P}$ & 0.881 & $2 \times 3$ & Jx I & 0.093 \\
\hline 5 & $3 \times 4$ & $\mathrm{P} \times \mathrm{P}$ & 0.968 & $2 \times 6$ & $\mathrm{~J} \times \mathrm{I}$ & 0.086 \\
\hline 6 & $4 \times 2$ & $\mathrm{P} \times \mathrm{P}$ & 0.955 & $1 \times 6$ & NE x I & 0.081 \\
\hline 7 & $2 \times 5$ & IN x IN & 0.911 & $14 \times 7$ & NE $x$ I & 0.093 \\
\hline 8 & $3 \times 1$ & IN x IN & 0.934 & $2 \times 13$ & S x I & 0.095 \\
\hline 9 & $15 \times 14$ & IN x IN & 0.996 & $2 \times 17$ & S X I & 0.098 \\
\hline 10 & $1 \times 2$ & $\mathrm{ExE}$ & 0.943 & $2 \times 2$ & S x IN & 0.091 \\
\hline 11 & $1 \times 10$ & Ex IN & 0.94 & $2 \times 5$ & S x IN & 0.086 \\
\hline 12 & $4 \times 14$ & E x IN & 0.875 & $2 \times 10$ & $\mathrm{~S} \times \mathrm{E}$ & 0.055 \\
\hline 13 & $3 \times 7$ & $\mathrm{BC} \times \mathrm{BC}$ & 0.839 & $2 \times 12$ & $\mathrm{~S} \times \mathrm{E}$ & 0.077 \\
\hline 14 & $5 \times 8$ & $\mathrm{BC} \times \mathrm{BC}$ & 0.845 & $7 \times 3$ & BG $x$ BC & 0.088 \\
\hline 15 & $4 \times 5$ & $\mathrm{~J} \times \mathrm{J}$ & 0.832 & $13 \times 2$ & $\mathrm{BG} \times \mathrm{BC}$ & 0.09 \\
\hline 16 & $3 \times 4$ & $\mathrm{~J} \times \mathrm{J}$ & 0.821 & $1 \times 2$ & I x J & 0.08 \\
\hline 17 & $3 \times 4$ & BG x J & 0.867 & $6 \times 1$ & I x J & 0.092 \\
\hline 18 & $3 \times 2$ & NE $x$ NE & 0.87 & $4 \times 13$ & I x NE & 0.099 \\
\hline 19 & $6 \times 11$ & NE $x$ NE & 0.928 & $6 \times 1$ & I $x$ NE & 0.085 \\
\hline 20 & $15 \times 14$ & NE $\times$ S & 0.853 & $6 \times 1$ & I x BG & 0.083 \\
\hline 21 & $14 \times 15$ & BG x BG & 0.846 & $6 \times 5$ & $\mathrm{I} \times \mathrm{BG}$ & 0.074 \\
\hline
\end{tabular}

For the species under study, the reproductive system probably caused the high polymorphism percentage, and consequently the high genetic diversity observed among the populations. Contrary results were obtained by Souza-Sobreira et al. (2015) in a study on the genetic diversity of natural populations of Pitcairnia flammea (L.) John (Bromeliaceae), who reported that the shortest distance was among individuals from the same population and the greatest distance was among populations.

Genetic relationships between individuals and populations were estimated based on a dendrogram produced by the Jaccard coefficient and the UPGMA, which resulted in five large clusters (I, II, III, IV, and V) and one individual (E10) that was clustered separately, which was the most divergent among the populations (Figure 3). This distance may indicate a significant differentiation process, which is the result of the genetic erosion that these individuals are subjected to in fragmented habitats in Sergipe State.

The high genetic variability found in mangaba may be a consequence of adaptation to habitat change; variation caused by selection pressure can maintain genetic polymorphisms (Sheng et al., 2004). Another factor that may cause high genetic variability in this species is the pollination mechanism it possesses, which reduces the loss of pollen, prevents autogamy, and favors cross-pollination (Darrault and Schlindwein, 2005). Luz et al. (2015) concluded that ISSR markers are effective in detecting genetic variability among Cratylia argentea (Desv.) Kuntze accessions. In a study on the genetic diversity of Cattleya labiata, ISSR markers effectively estimated the genetic variability of this species (Pinheiro et al., 2012).

The similarity data were in accordance with the PCoA results (Figure 4). Four groups were identified among the different populations, and the first two principal components explained $67.77 \%$ of the variation. This result confirms the effectiveness of ISSR markers and the existence of genetic diversity among the populations studied. A joint analysis of the UPGMA clustering and PCoA results revealed that individual E10 was the most divergent

Genetics and Molecular Research 15 (3): gmr.15038624 
because it was isolated from the other groups. Because of differences in ranking, optimization, and cluster classification, the use of more than one clustering method allows the classification to be complemented by the criteria that each technique uses, and prevents the adoption of erroneous inferences in the allocation of materials within a certain genotype subcluster (Silva et al., 2012a).

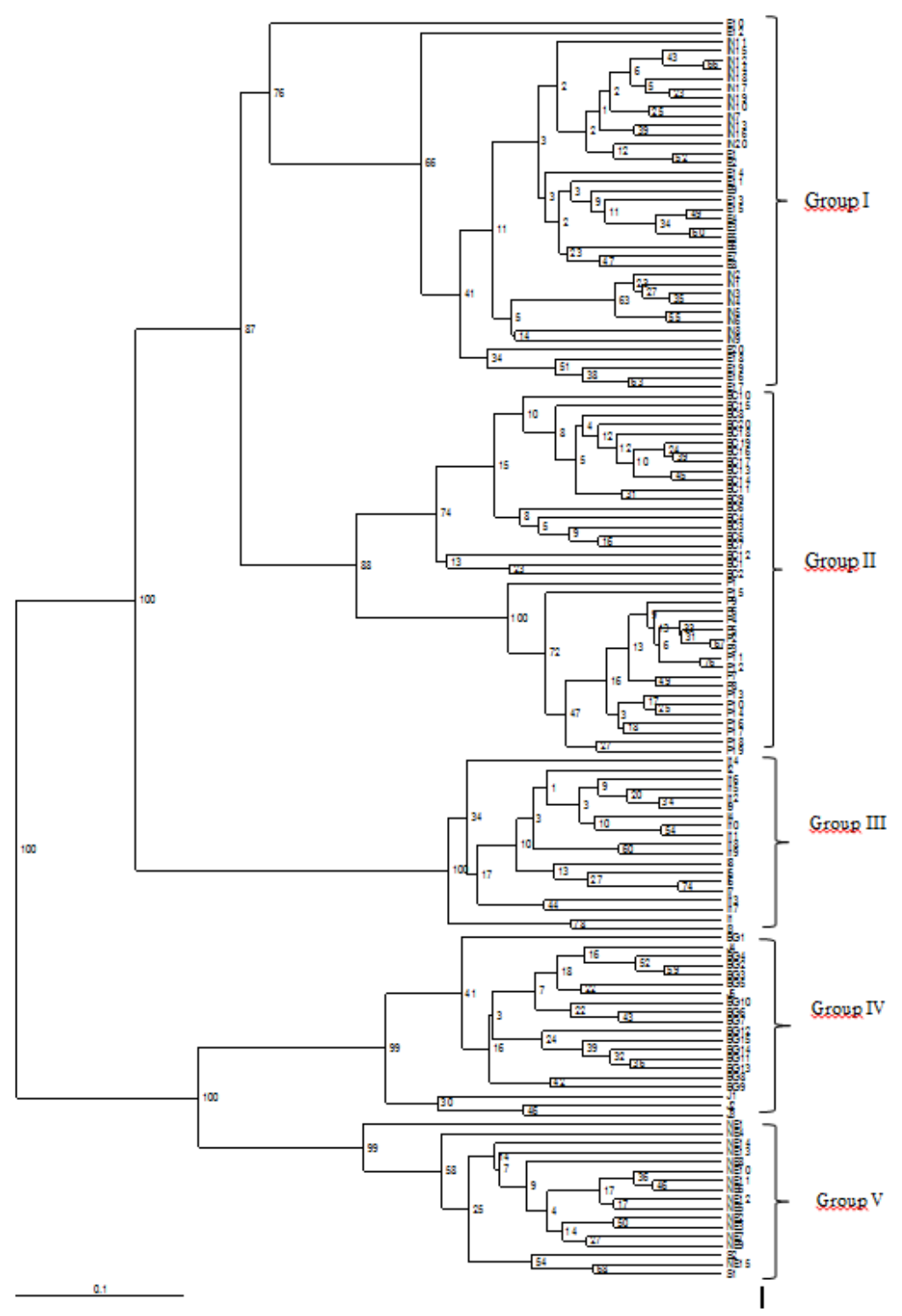

Figure 3. Phylogenetic representation by the UPGMA clustering method, genetic similarity by the Jacard coefficient (1908), and bootstrap analysis (10,000X) for 10 natural populations of Hancornia speciosa Gomes of the State of Sergipe, Brazil.

Genetics and Molecular Research 15 (3): gmr.15038624 


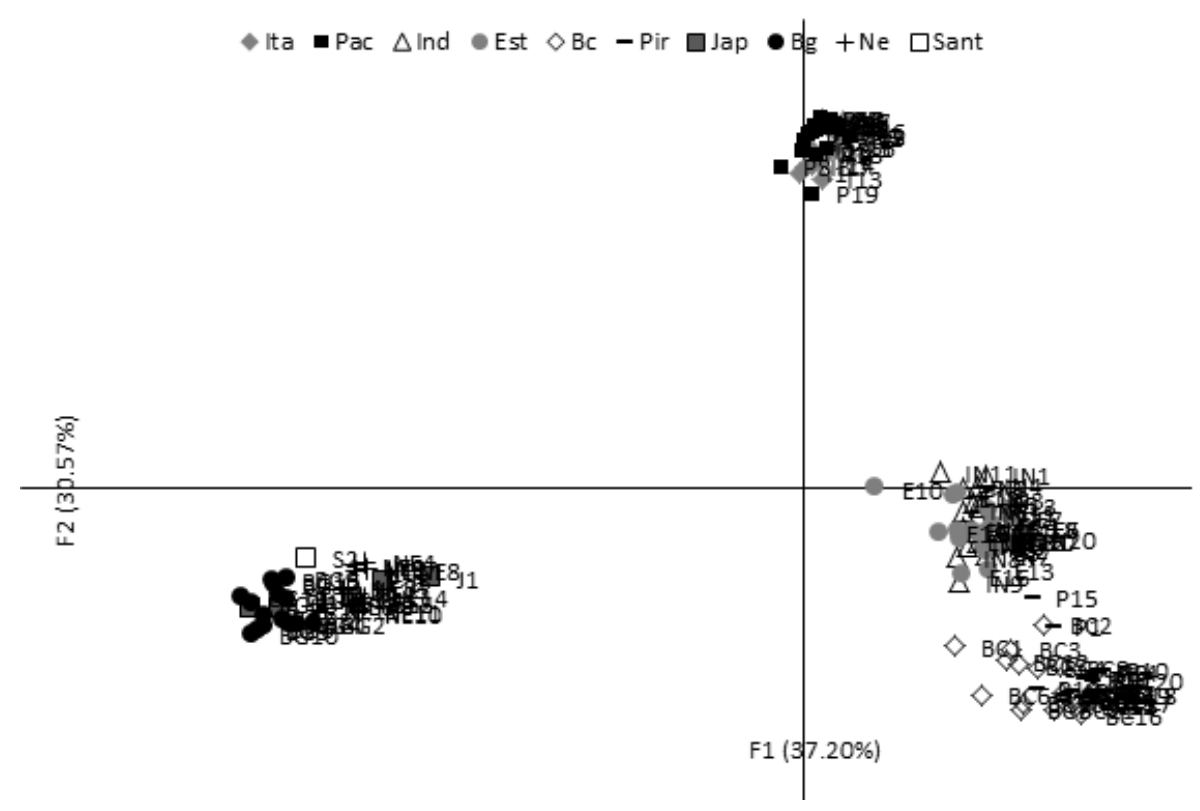

Figure 4. Principal coordinates analysis (PCoA) for natural populations of Hancornia speciosa Gomes of the State of Sergipe, Brazil.

Table 5 shows the results obtained by AMOVA, which indicate that most of the genetic diversity $(77 \%)$ was found between populations while $23 \%$ was within populations. Contrary results were found by Jimenez et al. (2015) in a study on natural mangaba populations.

Table 5. Analysis of molecular variance between and within 10 populations of Hancornia speciosa Gomes in the State of Sergipe, Brazil.

\begin{tabular}{l|c|c|c|c|c}
\hline Source of variation & d.f. & SS & MS & Variance components (CV) & Total (\%) \\
\hline Among populations & 9 & 2751.4 & 305.7 & 19.8 & 77 \\
\hline Within populations & 144 & 847.3 & 5.9 & 5.9 & 23 \\
\hline Total & 153 & 3598.7 & & 25.7 & 100 \\
\hline
\end{tabular}

d.f. - degrees of freedom; SS - sum of squares; MS - mean square; CV - coefficient of variation.

Large genetic variation exists within populations of tree species with mixed reproductive systems and efficient pollen and seed dispersion (Yun et al., 1998), which result in long-distance gene flow, reduced variation between populations, and increased variation within them (Loveless and Hamrick, 1984). The pattern we observed was not in accordance with those of other tree species, and with what is expected in allogamous species. In the mangaba population evaluated, gene flow could be restricted and consequently the intrapopulation diversity was low, whereas it was high among populations.

The genetic structures of plant populations are dependent upon the interactions of many different processes, such as habitat fragmentation and/or population isolation, range changes, mutation, ecology, reproductive isolation, genetic drift, reproductive mechanism, 
gene flow, and selection (Thendral Hepsibha et al., 2010). Genetic diversity greatly contributes to the sustainability of plant populations (Wang et al., 2007), and its study is necessary to understand what occurs in populations (Silva et al., 2012b).

Mangaba is an endangered species in northeastern Brazil, and Sergipe State is subject to high human activity. This compromises the survival of this species, which is part of the social and economic heritage of this state. Habitat fragmentation caused the main limitation of this study, as it was difficult to collect a large number of individuals in some populations. Studies that investigate species distributions and genetic compositions are very important for the conservation and improvement of this species. A good strategy for the effective conservation of the genetic variability of these genetic resources would be the conservation of populations in the geographical range of the species. This has been conducted by the maintenance of a mangaba gene bank and the creation of private natural heritage reserves. The mangaba gene bank of the Embrapa Coastal Tablelands is in Sergipe, and 1232.30 ha of private reserves exist, the largest being "Caju" reserve in Itaporanga d'Ajuda, with 763.37 ha (ICMBIO, 2016).

The ISSR markers used in this study were effective in estimating genetic variability between mangaba populations, and the high degree of polymorphism detected suggests that the genetic diversity of remnant populations in the State of Sergipe can provide important information for the conservation and future improvement of this species.

\section{Conflicts of interest}

The authors declare no conflict of interest.

\section{ACKNOWLEDGMENTS}

We thank CNPq for the split PhD scholarship granted to A.N.R. Soares (Process \#203542/2014-2) and the Embrapa Coastal Tablelands for assisting with the study.

\section{REFERENCES}

Alzate-Marin AL, Guidugli MC, Soriani HH, Martinez CA, et al. (2009). An efficient and rapid DNA minipreparation procedure suitable for PCR/SSR and RAPD analyses in tropical forest tree species. Braz. Arch. Biol. Technol. 5: 1217-1224. http://dx.doi.org/10.1590/S1516-89132009000500020

Amorim JAE, Silva AVC, Vitória MF and Ramos SR (2013). Diversidade genética de indivíduos de mangabeira oriundos do povoado Abaís, em Sergipe. Anais do $7^{\circ}$ Congresso Brasileiro de Melhoramento Vegetal, Uberlândia. Available at [http://ainfo.cnptia.embrapa.br/digital/bitstream/item/91073/1/diversidade-genetica-mangabeira-SE.pdf]

Amorim JAE, Mata LR, Lédo AS, Azevedo VCR, et al. (2015). Diversity and genetic structure of mangaba remnants in states of northeastern Brazil. Genet. Mol. Res. 14: 823-833. http://dx.doi.org/10.4238/2015.February.2.7

Barreira S, Sebbenn AM, Scolforo JRS and Kageyama PY (2006). Diversidade genética e sistema de reprodução em população nativa de Eremanthus erythropappus (DC.) MacLeish sob exploração. Sci. Forest. 71: 119-130.

Barros DI, Bruno RLA, Nunes HV, Silva GC, et al. (2006). Different extraction methods aiming mangaba seeds quality. Rev. Bras. Frutic. 28: 25-27. http://dx.doi.org/10.1590/S0100-29452006000100010

Black-Samuelsson S, Eriksson G, Gustafsson L and Gustafsson P (1997). RAPD and morphological analysis of the rare plant species Vicia pisiformis (Fabaceae). Biol. J. Linn. Soc. 61: 325-343.

Brandão MM, Vieira FA and Carvalho D (2011). Fine-scale genetic structure of Myrcia splendens (Myrtaceae). Rev. Árvore 35: 957-964.

Brown AHD and Weir BS (1983). Measuring genetic variability in plant populations. In: Isozymes in plant genetics and breeding, part A (Tanksley SD and Orton TJ, eds.). Elsevier, Amsterdam, 219-239.

Genetics and Molecular Research 15 (3): gmr.15038624 
Chagas KPT, Sousa RF, Farjado CG and Vieria FA (2015). Seleção de marcadores ISSR e diversidade genética em uma população de Elaeis guineensis. Rev. Bras. Cien. Agr. 10: 147-152.

Costa TS, Silva AVC, Lédo AS, Santos ARF, et al. (2011). Diversidade genética de acessos do banco de germoplasma de mangaba em Sergipe. Pesq. Agropec. Bras. 46: 499-508. http://dx.doi.org/10.1590/S0100-204X2011000500007

Darrault RO and Schlindwein C (2005). Limited fruit production in Hancornia speciosa (Apocynaceae) and pollination by nocturnal and diurnal insects with long mouth parts. Biotropica 37: 381-388. http://dx.doi.org/10.1111/j.17447429.2005.00050.x

Darrault RO and Schlindwein C (2006). Polinização. In: A cultura da mangabeira (Silva Junior JF and Ledo AS, Org.). Embrapa Tabuleiros Costeiros, Aracaju, 43-56.

Dias FTC, Bertini CHCM, Silva APM and Cavalcanti JJV (2015). Variabilidade genética de feijão-caupi de porte ereto e ciclo precoce analisada por marcadores RAPD e ISSR. Rer. Cien. Agr. 46: 563-572.

Doyle JJ and Doyle JL (1990). Isolation of plant DNA from fresh tissue. Focus 12: 13-15.

Ganga RMD, Ferreira GA, Chaves LJ and Naves RV (2010). Caracterização de frutos e árvores de populações naturais de Hancornia speciosa Gomes do cerrado. Rev. Bras. Frutic. 32: 101-113. http://dx.doi.org/10.1590/S0100$\underline{29452010005000019}$

Giustina LD, Luz LN, Vieira FS, Rossi FS, et al. (2014). Population structure and genetic diversity in natural populations of Theobroma speciosum Willd. Ex Spreng. (Malvaceae). Genet. Mol. Res. 13: 3510-3519. http://dx.doi. org $/ 10.4238 / 2014$.February. 14.5

ICMBIO (Instituto Chico Mendes MMA) (2016). Reservas particulares do patrimônio natural, RPPN, Sergipe. ICMBIO, Brazil. http://sistemas.icmbio.gov.br/simrppn/publico/detalhe/763/.

Jimenez HJ, Martins LSS, Montarroyos AVV, Silva Junior JF, et al. (2015). Genetic diversity of the neotropical tree Hancornia speciosa Gomes in natural populations in northeastern Brazil. Genet. Mol. Res. 14: 17749-17757. http:// dx.doi.org/10.4238/2015.December.21.48

Liu D, He X, Liu G and Huang B (2011). Genetic diversity and phylogenetic relationship of Tadehagi in southwest China evaluated by inter-simple sequence repeat (ISSR). Genet. Res. Crop Evol. 58: 679-688. http://dx.doi.org/10.1007/ s10722-010-9611-3

Lorenzoni RM, Soares TCB, Santiago VF, Silva JA, et al. (2014). Utilização de marcadores ISSR na avaliação da divergência genética entre acessos de biribazeiro. Rev. Bras. Frutic. 36: 251-257. http://dx.doi.org/10.1590/S010029452014000500029

Loveless MD and Hamrick JL (1984). Ecological determinants of genetic structure in plant populations. Annu. Rev. Ecol. Syst. 15: 65-95. http://dx.doi.org/10.1146/annurev.es.15.110184.000433

Luz GA, Gomes SO, Araujo Neto RB, Nascimento MSCB, et al. (2015). Molecular characterization of accessions of Cratylia argentea (Camaratuba) using ISSR markers. Genet. Mol. Res. 14: 15242-15248. http://dx.doi. org/10.4238/2015.November.25.12

Lynch M and Milligan BG (1994). Analysis of population genetic structure with RAPD markers. Mol. Ecol. 3: 91-99. http://dx.doi.org/10.1111/j.1365-294X.1994.tb00109.x

Morales RGF, Resende JTV, Faria MV, Silva PR, et al. (2011). Divergência genética em cultivares de morangueiro, baseada em caracteres morfoagronômicos. Rev. Ceres 3: 323-329. http://dx.doi.org/10.1590/S0034-737X2011000300012

Page RDM (1996). TreeView: an application to display phylogenetic trees on personal computers. Comput. Appl. Biosci. 12: $357-358$

Peakall R and Smouse PE (2006). GENALEX 6: genetic analysis in Excel. Population genetic software for teaching and research. Mol. Ecol. Notes 6: 288-295. http://dx.doi.org/10.1111/j.1471-8286.2005.01155.x

Pinheiro LR, Rabbani ARC, Silva AVC, Lédo AS, et al. (2012). Genetic diversity and population structure in the Brazilian Cattleya labiata (Orchidaceae) using RAPD and ISSR markers. Plant Syst. Evol. 298: 1815-1825. http://dx.doi. org/10.1007/s00606-012-0682-9

Rivas LH, Giustina LD, Luz LN, Karsburg IV, et al. (2013). Genetic diversity in natural populations of Theobroma subincanum Mart. in the Brazilian Amazon. Genet. Mol. Res. 12: 4998-5006. http://dx.doi.org/10.4238/2013. October.24.12

Santana IBB, Oliveira EJ, Soares-Filho WS, Ritzinger R, et al. (2011). Variabilidade genética entre acessos de umbucajazeira mediante análise de marcadores ISSR. Rev. Bras. Frutic. 33: 868-876. http://dx.doi.org/10.1590/S010029452011005000090

Santos PCG, Alves EU, Guedes RS, Silva KB, et al. (2010). Quality of Hancornia speciosa Gomes seeds in function of drying periods. Semina: Cienc. Agric. 31: 343-352.

Sheng Y, Zheng WH, Pei KQ and Ma KP (2004). Population genetic structure of a dominant desert tree, Haloxylon ammodendron (Chenopodiaceae), in the southeast Gurbantunggut Desert detected by RAPD and ISSR markers. Acta

Genetics and Molecular Research 15 (3): gmr.15038624 
Bot. Sin. 46: 675-681.

Silva AVC, Santos ARF, Lédo AS, Feitosa RB, et al. (2012a). Moringa genetic diversity from Germplasm Bank using RAPD markers. Trop. Subtrop. Agroecosyst. 15: 31-39.

Silva AVC, Rabbani ARC, Sena-Filho JG, Almeida CS, et al. (2012b). Genetic diversity analysis of mangaba (Hancornia speciosa Gomes), an exotic Brazilian tropical species. Trop. Subtrop. Agroecosyst. 15: 217-225.

Souza LMFI, Kageyama PY and Sebbenn AM (2004). Estrutura genética em populações fragmentadas de Chorisia speciosa St. Hil (Bombacaceae). Sci. Forest. 65: 70-79.

Souza-Sobreira FB, Souza GB, Rosado CCG, Miranda FD, et al. (2015). Genetic diversity in three natural populations of Pitcairnia flammea (1.) John (Bromeliaceae) estimated by ISSR markers. Genet. Mol. Res. 14: 15892-15901. http:// dx.doi.org/10.4238/2015.December.3.1

Thendral Hepsibha B, Premalakshmi V and Sekar T (2010). Genetic diversity in Azima tetracantha (Lam) assessed through RAPD analysis. Indian J. Sci. Technol. 3: 170-173.

Uysal H, Yong-Bi F, Kurt O, Peterson GW, et al. (2010). Genetic diversity of cultivated flax (Linum usitatissimum L.) as revealed by ISSR markers. Genet. Res. Crop Evol. 57: 1109-1119. http://dx.doi.org/10.1007/s10722-010-9551-y

Wang W, Chen L, Yang P, Hou L, et al. (2007). Assessing genetic diversity of populations of top mouth culter (Culteral burnus) in China using AFLP markers. Biochem. Syst. Ecol. 35: 662-669. http://dx.doi.org/10.1016/j.bse.2007.04.008

Yun R, Zhong M, Wang H-X, Wei W, et al. (1998). Study on DNA diversity of Liaodong oak population at Dongling Mountain Region, Beijing. Acta Bot. Sin. 40: 169-175.

Zanella CM, Janke A, Palma-Silva C, Kaltchuk-Santos E, et al. (2012). Genetics, evolution and conservation of Bromeliaceae. Genet. Mol. Biol. 35: 1020-1026. http://dx.doi.org/10.1590/S1415-47572012000600017

Genetics and Molecular Research 15 (3): gmr.15038624 